\title{
7. \\ FOTEZOV PRIJEVOD NĚMEČEKOVA \\ ROMANA ĐAVO GOVORI ŠPANJOLSKI \\ (1940.) NASPRAM NJEGOVIH PUTOPISA \\ IZ THEATRALIA (1944.)
}

\section{Miranda Levanat-Peričić}

UDK: 821.162.3Nemeček, Z.:821.163.42Fotez,M.

Izvorni znanstveni članak

Sažetak: Fotezov prijevod Němečekova romana Đavo govori španjolski, koji je u okupiranom Pragu 1939. godine Francovom intervencijom bio zabranjen čim je izišao, objavljen je u predratnom Zagrebu 1940. i do danas je ostao jedini strani prijevod te knjige. Na intrigantno pitanje o ključnim i spornim mjestima Němečekova romana, koja su s jedne strane uznemirila Franca, a s druge potaknula Foteza na prijevod, lakše je odgovoriti u slučaju Francove intervencije, imajući u vidu Němečekovo zagovaranje autonomne Katalonije. Nešto je teže otkriti Fotezovu motivaciju budući da se u romanu, uz naklonost Kataloniji, postupno izgrađuje vrijednosni sustav utemeljen na rodno i rasno diskriminatornom diskursu, koji se aktualizira kad se otvaraju teme tijela, porijekla, roda i društvenog ustroja. Stoga se Fotezovoj motivaciji pristupa i posredno, poredbenom analizom imagološkog diskursa češkog pisca i hrvatskog prevoditelja, koji je u vrijeme kada je objavljen Němečekov roman putovao po Njemačkoj i Italiji, bilježeći dojmove s aktualnih kazališnih manifestacija. Stavljajući u suodnos dva dnevnička putopisa nastala u doba „sumraka Europe” - Němečekov fiktivni i zabranjeni zapis o španjolskom građanskom ratu i Fotezov stvarni zapis s putovanja po europskim ratnim kazalištima, objavljen 1944. pod naslovom Theatralie - u radu se propituje pripadnost istom/različitom kulturnom imaginariju obzirom na heteropredodžbe i stereotipne nacionalne karakterizacije (imageme), zastupljene u navedenim tekstovima.

Ključne riječi: Zdenek Němeček, Marko Fotez, Španjolski građanski rat, kulturni imaginarij, rasistički diskurs

\section{Uvod u komparativnu imagologiju putopisnog diskursa Marko Foteza i Zdeněka Němečeka}

oman o Španjolskom građanskom ratu češkog pisca i diplomata Zdeněka Němečeka (1894.-1957.) Dáabl mluvi španèlsky objavljen je u okupiranom Pragu 1939. godine, da bi ubrzo, nakon što je uslijedio Francov konzularni prosvjed, knjiga bila zabranjena. Sljedeće 
godine, 1940., u predratnom Zagrebu objavljen je prijevod Marka Foteza pod naslovom Đavo govori španjolski, što je do danas ostao jedini prijevod te knjige. Time je ova knjiga o umjetniku u ratu postala sjecištem kompleksnih izvanknjiževnih okolnosti i zauvijek ostala poveznicom dviju intelektualnih sudbina, češkog pisca i hrvatskog prevoditelja. Ta knjiška veza međutim ne bi bila toliko ekskluzivna da nije riječ o dvjema, toliko različitim ratnim biografijama, da svaka mogućnost preklapanja njihovih životnih kolosijeka djeluje kao izniman otklon.

Kada je objavljen Němečekov roman, Marko Fotez je putujući po Njemačkoj i Italiji bilježio dojmove s aktualnih kazališnih manifestacija i pritom nastojao umaći zloduhu vremena. Putopisni eskapizam kojim je pokušavao demantirati da među oružjem muze šute (čak i onda kada su te muze pod punom ratnom spremom, kao u Heidelbergu 1934. i na Mozartovu tjednu u Beču 1941.), Fotez je objavio 1944. godine, u vrijeme kada je Zdeněk Němeček bio aktivno uključen u pokret otpora, a uskoro i zarobljen u Gestapovom praškom zatvoru. Němečekov život bio je većim dijelom vezan uz egzil, dobrovoljni i prisilni, a za njegovo intelektualno sazrijevanje od najranije mladosti ključno je bilo iskustvo rata. Kao pripadnik čehoslovačke legije u Ukrajini iz blizine je promatrao Prvi svjetski rat, potom Februarsku revoluciju u carskoj Rusiji, pa Španjolski građanski rat i njemačku okupaciju Čehoslovačke da bi se nakon oslobođenja i komunističkog prevrata u Čehoslovačkoj, odlučio na život disidenta. Radeći u visokim konzularnim predstavništvima Nürnberga (1922.-1923.), New Yorka (1926.-1929.), Marseillea (1932.-1936.), Madrida i Barcelone (1938.), imao je prilike, po vlastitim riječima, „ručati s kraljevima, upoznati Staljina i Višinskog, otvarati izložbe, sjeći vrpce i dobiti batine u Gestapovu zatvoru”.' Pored svega toga, svoj je život smatrao običnim životom „nekoga tko je rođen u srcu Europe, na pedeset stupnjeva geografske širine”. ${ }^{2}$

Za razliku od Nemečeka - čija su književna djela, uključujući i roman koji je preveo Fotez, u ratu bila zabranjivana - karijera Marka Foteza u ratnom se razdoblju razvijala bez zastoja, smjerom kojim je krenuo još u predratno vrijeme, kada je, odmah nakon mature, ušao u zagrebačko kazalište kao pomoćni redatelj Gavelle i Strozzija. U sezoni 1935./1936. bio je tajnik drame u HNK; u sezoni 1940./1941. ravnatelj drame u Splitu; a 1941./1942. istu je funkciju imao u Osijeku. U ratnom je razdoblju, 1943., doktorirao filozofiju. Radovi koji se bave Fotezovim životom i djelom neposredno (Bogner-Šaban, 1989.) i posredno (Banović, 2012. $)^{3}$ ne zalaze izvan poznatih činjenica o Fotezovoj čistoj kazališnoj i akademskoj

Zdenek Nemecek Papers. Yale University Library. Beinecke Rare Book and Manuscript Library (http://drs.library.yale. edu:8083/HLTransformer/HLTransServlet?stylename=yul.ead2002.xhtml.xsl\&pid=beinecke:nemecek\&query=\&cl ear-stylesheet-cache=yes\&hlon=yes\&big=\&adv=\&filter=\&hitPageStart $=\&$ sortFields=\&view=over \#did)

Isto.

Iako se Snježana Banović u svojoj studiji bavi upravo ratnim kazališnim prilikama, Foteza nijednom ne spominje u bilo kakvom političkom kontekstu, nego isključivo u osvrtima na njegove teatarske angažmane. Nasuprot tomu, Antonija Bogner-Šaban u svojoj monografiji o Fotezu, gotovo da i ne spominje rat i političke prilike, tako da i u njezinoj studiji društveni i politički kontekst Fotezova teatrološkog rada ostaje nerasvijetljen. U uzgrednim opaskama o kazališnoj i kulturnoj pozornici Osijeka u vrijeme kada Fotez postaje direktorom drame, Antonija Bogner-Šaban iznosi vrlo neobičnu primjedbu: „Lokalni dnevnik Hrvatski list, koji je uspio zadržati izrazito nacionalnu orijentaciju i u vihoru rata, redovito prati događaje u kazalištu i oko njega". (Antonija BOGNER-ŠABAN, Marko Fotez - život i djelo, Čakovec 1989., 108.) Tvrdnja da list nacionalne orijentacije uspijeva zadržati nacionalnu orijentaciju u državi koja je utemeljena na nacionalnoj isključivosti, kada to nije postignuće koje traži velika odricanja, čini se barem promašenim zaključkom. Općenito, Antonija Bogner-Šaban vrlo je suzdržana u komentarima povijesnih okolnosti i uglavnom izbjegava dotaknuti političke prilike u ratnom Osijeku. Tako na primjer, prateći Fotezov rad u okolnostima kada se kao gost-redatelj vraća u Osijek nakon godinu i pola dana izbivanja (budući da je u Osijeku direktorom drame bio od 4. rujna 1941. do travnja 1942., to je moglo biti u drugoj polovici 1943. godine) ona piše: „(...)situacija je izmijenjena u Hrvatskom narodnom kazalištu. Jedan dio ansambla napustio je teatar, i to je jednim od uzroka da repertoar nije 
karijeri. Fotezovi interesi za djela starije hrvatske književnosti dobro su se uklopili u ratni program „državnog kazališta” kojemu je imperativ bio oživljavanje djela nacionalne baštine. U tom smislu Snježana Banović spominje premijeru Držićeva Plakira 26. svibnja 1943. u Fotezovoj režiji, ${ }^{4}$ zatim u siječnju 1943. svečano obilježavanje 100. izvedbe Dunda Maroja u Fotezovoj obradi. ${ }^{5}$ Djelima starije hrvatske književnosti predstavio se i splitskoj i osječkoj publici nakon što je imenovan ravnateljem drame tamošnjih kazališta, pa je izvedbom Marulićeve Judite u njegovoj režiji svečano otvoreno Hrvatsko narodno kazalište u Splitu 15. prosinca 1940. godine, ${ }^{6}$ a 1. listopada 1941. u Osječkom HNK predstavio se premijerom Gundulićeve Dubravke. ${ }^{7}$ Osim toga je u Osijeku režirao Fausta, omiljeno djelo njemačkih ratnokazališnih repertoara. Dvije njegove drame praizvedene su u to ratno vrijeme - Ujak u Osijeku 27. siječnja 1944. i Cetvorka 3. ožujka 1945. u zagrebačkom HDK. ${ }^{8}$

Premda je pitanje zašto je Marko Fotez izabrao i preveo baš Němečekov roman za nas možda intrigantnije i od pitanja zašto je taj roman zabranjen, ono navodi (i zavodi) na ispitivanje prirode veze češkog pisca i hrvatskog prevoditelja kroz procjenu njihova osobnog angažmana u ratu, u što se ne bismo smjeli upuštati bez komparativne analize njihova diskursa o ratu. Stoga bi kontrapunktno čitanje njihovih putopisnih tekstova, odnosno Němečekove fiktivne ratne reportaže i odlomaka iz Fotezovih Theatralia, moglo biti polazištem usporedbe dvaju različitih imagotipskih sustava.

\section{Putovanje Miroslava Roušara ili viteška misija češkog slikara u španjolskom ratu}

Budući da predstavlja promjenu i oblikuje vremenski slijed kao niz zgoda, putovanje je uvijek vezano uz spoznaju. ${ }^{9}$ Nemečekov je roman o putovanju istodobno i niz zgoda kojima se jasno aludira na Don Quijotea, ali ujedno i putovanje s misijom koja je predstavljena kao donkihotovska, prije svega po idealističkim ciljevima koje sebi postavlja putnik, češki slikar Miroslav Roušar. Na svom putu po Španjolskoj usred vi-

oblikovan po nekoj umjetničkoj ili estetičkoj logici, već se izvode djela različite vrijednosti i žanra”. (Isto, 111.) Zašto i pod kakvim okolnostima je jedan dio ansambla „napustio teatar” autorica nam, nažalost, ostavlja nerazjašnjenim. To možda nije predmet njena interesa, ali stvara kontekstualnu lakunu. Zanimljiv je osvrt na ratno kazališno vrijeme dala Fotezova supruga Marija Crnobori u nedavno objavljenoj esejiziranoj biografiji. No, i u njezinim zabilješkama, o Fotezu u ratu saznajemo opet posredno, u sjećanjima posvećenim Titu Strozziju, u pismu koje je 6 . svibnja 1941. napisao Fotezu: „Kod prosuđivanja tvog štimunga, naći ćeš i moj. Vrlo je sumoran i tjeskoban (...) Gavella je bio tri noći u bajboku, što je na nj strašno djelovalo. Ovamo su se vratili svi glumci, i Grgović i Vujatović, a danas zadnji, Repak. U teatru se nastavlja ‘čišćenje’. Ja nikako neću na neko odgovorno mjesto. Pitano je i Kombola i on je odbio”. Zatim se Marija Crnobori prisjeća velike žalosti koju je Strozzi proživljavao nakon što je mladi glumac Ivan Štrk obješen i kasnije nakon nestanka mladog kolege Veljka Kavića. (Marija CRNOBORI, Životić. Eseji, kazališni i ini, Pula 2011., 207.-208.) Sjećanja na Tita Strozzija Marije Crnobori rasvjetljavaju i dio Fotezova ratnog razdoblje - saznajemo, iako tek posredno, da su Fotezova razmišljanja bliska Strozzijevim kad je u pitanju raspoloženje, no ne i kada je u pitanju „odgovorno mjesto” u kazalištu.

Snježana BANOVIĆ, Država i njezino kazalište. Hrvatsko državno kazalište u Zagrebu 1941. - 1945., Zagreb 2012., 114.

Isto, 241.

A. BOGNER-ŠABAN, Marko Fotez - život i djelo, 104.

Isto, 108.

A. BOGNER-ŠABAN, Marko Fotez-život i djelo, 171. S. BANOVIĆ, Država i njezino kazalište, 153.

Usp. Dean DUDA, Priča i putovanje. Hrvatski romantičarski putopis kao pripovjedni žanr, Zagreb 1998., 42. 
hora građanskog rata Roušar traži odgovore na pitanja o razlozima sukoba koji naziva bratoubilačkim, koji je, u skladu s naslovom, predstavljen kao rat među govornicima istog jezika - „Zašto dakle toliko krvi, zašto toliko mržnje među ljudima koji govore istim jezikom?" 10 Njegovo je putovanje stoga određeno lingvističkom kartom i odvija se u granicama zastupljenosti katalonskog jezika, pa kreće od jednog sela u francuskoj pokrajini Rousillon, gdje se govori katalonski, a završava u Barceloni, administrativnom i kulturnom središtu Katalonije, koja je tada pod kontrolom republikanske vlade postala metom napada pobunjenih generala koje predvodi Franco. Pripovjedačeva priklonjenost Kataloniji izražava se i tvrdnjom da „đavo govori svim jezicima i narječjima, a u ovaj čas on govori španjolski”. ${ }^{11}$ Taj zaključak slijedi nakon susreta s dezerterima koju mu pripovijedanju kako su govornici kastiljskog, odnosno pripadnici republikanske vojske, zapalili crkvu u njihovu katalonskom selu. Španjolski i kastiljski jezik u Nemečekovu romanu vrednuju se dakle kao isti idiom, koji se jasno razlikuje od katalonskog jezika.

Budući da je oslabljena dogadajna struktura jedno od osnovnih obilježja putopisne narativnosti, ${ }^{12}$ taj se nedostatak nadomješta drugim sredstvima, u ovom slučaju dijalozima koje Roušar vodi pri slučajnim susretima - sugovornicima koji u donkihotovskoj paradigmi zauzimaju Sanchovo mjesto. Budući da je u Nemečekovu djelu riječ o fikciji „presvučenoj” putopisnim žanrom, u „slučajnim” susretima zapravo se predstavljaju sugovornici izabrani kao svojevrsni reprezentativni uzorci španjolskog povijesnog trenutka, a dijalozi se odvijaju prema istom obrascu - Roušar postavlja pitanje na koje svi spremno i bez sustezanja odgovaraju dugim monolozima. U nizu dijaloških „zgoda” Roušar redom susreće španjolske izbjeglice, Rome, katalonskog pastira, katalonske vojne dezertere, napuštenu mladu ženu slikaricu, katalonskog veleposjednika, anarhistu, slikara i njegov model, liječnika, baskijskog odvjetnika koji je postao republikanski vojnik, a na kraju pogiba u zračnom napadu, uz obalu mora razmišljajući o njegovoj olovnoj boji.

Svi likovi uvode se na isti način; nakon upoznavanja slijedi pitanje o razlozima rata, a oni bez odlaganja, u dugim monolozima iznose neku privatnu tragediju koja predstavlja exemplum. Iako se čini da raspolaže s bogatim katalogom tipova sugovornika, Roušarovi informatori međusobno se bitno ne razlikuju, pa u reprezentaciji ratnih „činjenica” prevladava nametljiva selekcija određenih motiva koji se uzastopce javljaju - tako je, primjerice, paljenje crkava, progon i ubijanje svećenika problem koji muči i republikanske vojnike i dezertere republikanske vojske. $U z$ to, u romanu se postupno izgrađuje vrijednosni sustav utemeljen na rodno i rasno diskriminatornom diskursu, koji se aktualizira kadgod se otvaraju teme tijela, porijekla, društvenog ustroja i uloge žene. Razmotrit ćemo navedeno redom.

10 Zdeněk NĚMEČEK, Đavo govori španjolski, (preveo Marko Fotez), Zagreb 1940., 79.

11 Isto, 59.

12 D. DUDA, Priča i putovanje, 54. 


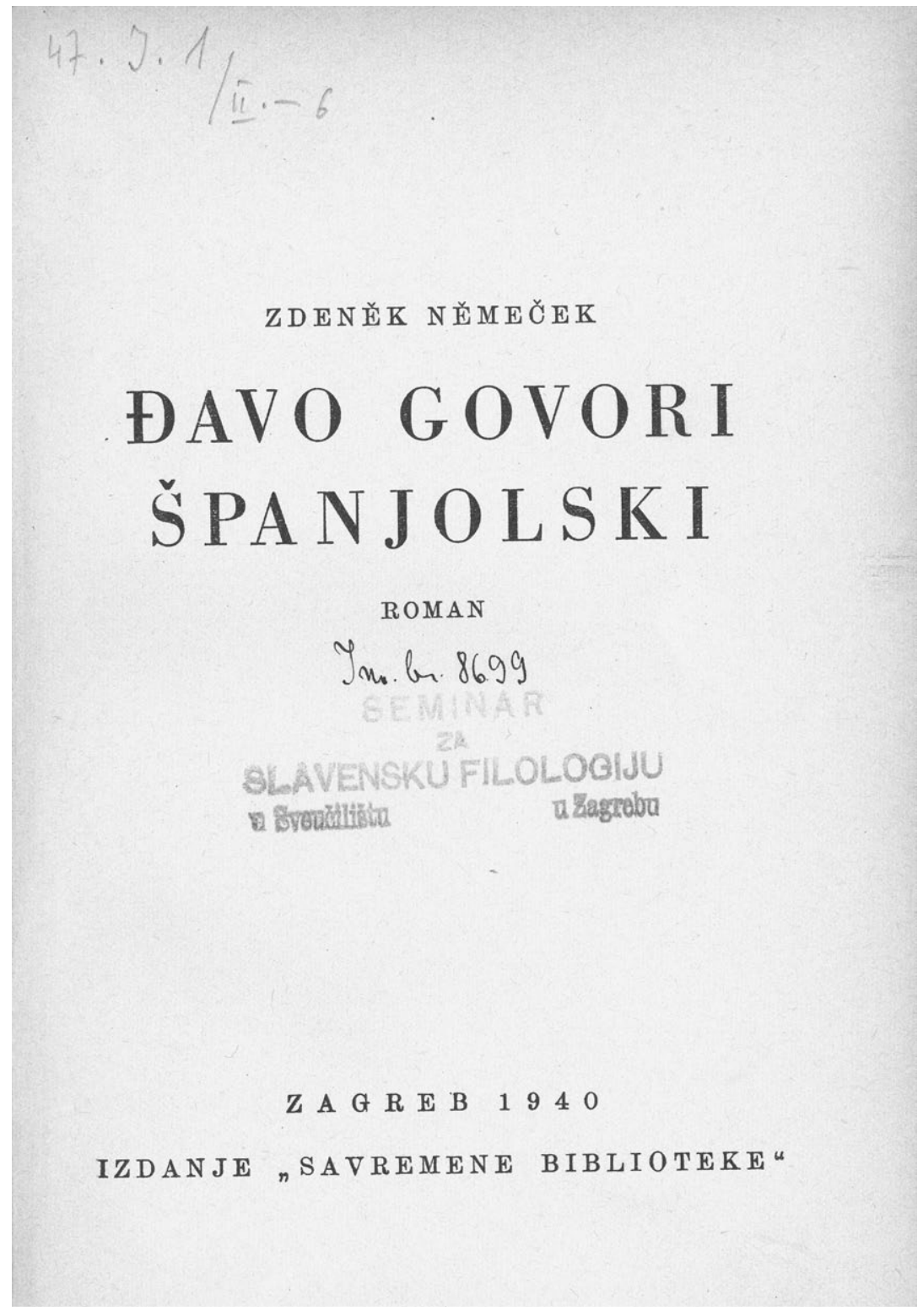

Slika 1. Đavo u Kataloniji govorio je španjolski. Zašto je Fotez objavio prijevod Němečekove knjige u Zagrebu 1940. godine?

\section{1. Tijelo i „rasa”}

Među pripovjednim postupcima istaknutu ulogu u Nemečekovu romanu ima opis tjelesnog izgleda, ustanovljen na ponavljanju određenog obrasca u kojemu se velika pozornost posvećuje vrednovanju tijela u smislu određenja „rasnih” obilježja. Dok su pri opisu krajolika, Roušarovi dojmovi podređeni „slikarskim” zapažanjima oblika, boje i tehnika slikanja, opis ljudskog tijela svodi se na stereotipno detektiranje „rasnih” ka- 


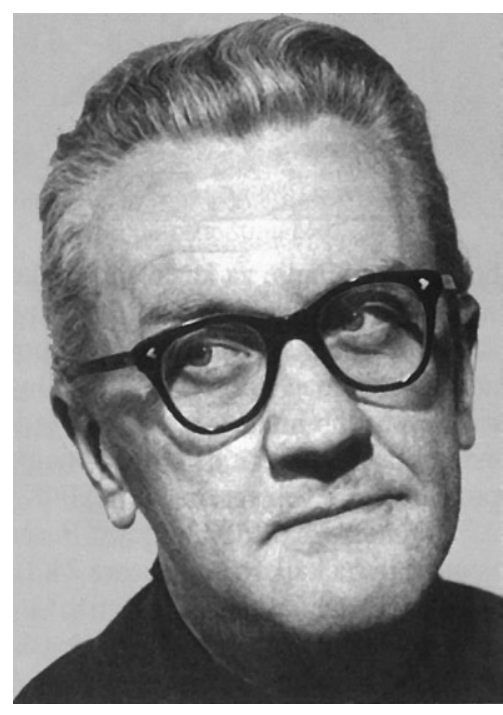

Slika 2. Marko Fotez

rakteristika. Na putu iz rousillonskog sela na granici s Katalonijom pri susretu s izbjeglicama iz Španjolske, ali i u kući odvjetnika Milansa, Nemečekov Roušar uočava i izdvaja "rasnu pripadnost” i „oznake rase” svojih sugovornika:

Stariji od njih, slabašnijeg srednjeg rasta, tamnih duboko usađenih očiju, gustih obrva i velikih ustiju, neizglađenih rastrganih gesta, dakle onaj tip što prevladava u Andaluziji i zadire u obje Kastilije (...) Drugi pak, mlađi i jači, bez osobitih rasnih oznaka, čovjek kome bi kolijevka mogla biti bilo gdje u Evropi. ${ }^{13}$

(...) Ovdje su bile još dvije služavke i vrtlar, čovjek odnekud iz Asturije, sjajan primjerak španjolske rase sa sjevera. ${ }^{14}$

Kada prelazi francusko-španjolsku granicu i ulazi u Kataloniju, susreće mladog katalonskog pastira i uvrštava ga među „čiste latinske tipove” Europljana. Taj će „čisti” tip „latinske rase”, u osebujnoj rasnoj (zapravo posve rasističkoj) hijerarhiji koju će iznjedriti roman, predstavljati središnji predmet pripovjedačke adoracije.

Taj dječak (...) bio je to čisti latinski tip - prema ljestvici u koju smo svrstali lica Evropljana. Njegove su geste bile neizvještačene i gipke, vladao se jednostavno, a takav je bio i njegov način gostoprimstva. ${ }^{15}$

Katalonski je pastir „čisti latinski tip” u usporedbi sa španjolskim izbjeglicama iz Andaluzije i Kastilje koje odlikuje slaba tjelesna građa, guste obrve, debele usne, neuglađeni pokreti. Isticanje latinskog/antičkog/rimskog u smislu vrednovanja muške ljepote izrazito je naglašeno u romanu. Ponavlja se i pri upoznavanju s liječnikom aristokratskog porijekla, Juanom de Retésom.

Liječnik, koji je ušao, imao je lijepu glavu rimskoga satnika iz jedne muzejske dvorane. Pravilne, upravo divne latinske crte, i dobar pogled..$^{16}$

Tjelesni opisi lako prelaze u prosudbu o ponašanju; fizički tip time se promovira u kulturni tip - od lijepe glave „latinskog tipa” do neizvještačenosti, gostoljubivosti i „dobrog pogleda”. Ovdje je nesumnjivo riječ o esencijalizirajućem diskursu koji vezuje „rasno", tj. fiziološko i biološko uz sferu kulture, duha i uljudbe. Takva narativna strategija ponegdje dosiže fiziognomičku karikaturalnost, pa se već po izgledu anarhista Puiga „vidi” da čita Bakunjina i Kropotkina, kao da ga je tjelesno formirala anarhistička literatura. Opis upućuje na zaključak da se njegov izgled i program stranke kojoj pripada ne razlikuju bitno.

\footnotetext{
Z. NĚMEČEK, Đavo govori španjolski, 45.

Isto, 108.

Isto, 55 .

16 Isto, 197.
} 
Bio je to čovjek niska rasta i širokih ramena, crnog divljeg lica, bundžija jastrebova pogleda, jakih ruku poput kladiva. Kretnje je imao oštre i rastrgane. Kad je šutio imao je usta čvrsto zatvorena, kad je progovorio, zasjali su mu sjajni, čvrsti zubi. Bio je mračan i odrješit. Prema uvaženom odvjetniku gajio je poštovanje, ali je to gajenje išlo vrlo sporo. ${ }^{17}$

\section{2. Porijeklo i „čistoća krvi”}

Osim što se „latinski tip” iskristalizirao kao vrijednosna kategorija, u romanu je, u skladu sa španjolskim nacionalnim opsesijama, otvoreno istaknut imperativ „čistoće krvi” (limpieza de sangre), što otvara prostor vrlo degradirajućim prosudbama o Drugima. Predmet pejorativnih primjedbi najčešće su Arapi i Romi.

Španjolski muškarac - nema li u sebi krvi berberske, ili kako se uljudnije kaže arapske - nosi na sebi često točnu ukočenost antiknog tipa. Linearni sklad visokog čela, uskog i ravnog nosa, tvrdih usana i istaknute brade, često mu daje izgled rimskog senatora, tako kako ga mi sebi rado predstavljamo. To je maska uzvišenosti i snage, za koju nisu potrebni ni um ni naobrazba. Ali svakako ponos, suvereni individualizam, gospodstvo, a često i sklonost nasilju. ${ }^{18}$

Nekoliko je otvorenih rasističkih predrasuda istaknuto u ovom ulomku - prije svega, „latinska" (isključivo muška) tjelesna ljepota moguća je samo bez miješanja krvi, osobito s Arapima. Zatim, toj „uzvišenosti i snazi” da bi se istaknula nije potreban ni um ni naobrazba, jer je ta vrijednost zadana po sebi, ona je biološko svojstvo i ne traži kulturnu nadgradnju.

Već na početku romana, Roušar susreće Rome koji bježe preko francuske granice, a razloge bijega objašnjavaju time što u Španjolskoj „svi sada jedu ono što su Cigani nekad jeli, pa je njima uzmanjkalo". ${ }^{19}$ To je povod pripovjedačeve krajnje neukusne, no vrlo strastvene usporedbe „španjolskog carstva nad kojim sunce nikada nije zalazilo” i u kojemu su živjeli „najčastohlepniji i najponosniji ljudi koje je zemlja ikad nosila” s Romima koji su „pratip animalnog bića”, koji živi na „nizini civilizacije”: ${ }^{20}$

I dođe ciganin, pratip animalnog bića, koji živi od otpadaka i radi iz nužde, i potuži se na narod od kojega je izravno ili neizravno živio...i kako je to rekao? Sramota...Da poslužio se riječima „verguenza” - i pljunuo (...) Ciganin, čovjek iz nizine civilizacije koji je zaostao za mnoga stoljeća, udario je žig sramote gospodi od koje je živio, i rekao je sud onih najzapuštenijih. ${ }^{21}$

\section{3. Patrijarhat i tradicija kao mistična veza „krvi i tla”}

Miroslav Roušar u kuću katalonske obitelj Milans, koja je plemićki naslov i grb stekla u borbi s Maurima u 8. stoljeću, dolazi u nedjelju te zajedno s njima preko radija sluša pri-

\footnotetext{
Isto, 141.

Isto, 178.

Isto, 52.

20 Isto, 53.
}

21 Isto. 
jenos mise iz crkve Svetog Petra u Rimu moleći se za zdravlje malog Ricarda, koji je teško bolestan. Iako bolesni dječak ima sestricu, svi se u obitelji njegove smrti pribojavaju jer bi za njih to bio kraj obiteljske loze:

U kući umire dječak. Ricardo se zove (...) Sjedim pred vrlo starim gnijezdom neke obitelji Milansa, o kojoj nisam nikad ništa čuo, a koja živi u patrijarhalnom redoslijedu na ovom komadiću zemlje-hraniteljice. Ovdje unutra odigrava se tragedija u najužem krugu porodice. Izginut će muško koljeno. A onda? Koji će se tuđinci ovamo priženiti ili doseliti? No, što onda? (...) Tko će progutati imanje? ${ }^{22}$

Čini se da Ricardova mala sestra ne samo da nije produžetak obitelji nego potencijalna opasnost - ona će dovesti tuđince! Dakle, u slučaju da jedini sin i nasljednik umre, ne bi bilo dobro ni da kći preživi. U međuvremenu, ta se neugoda rješava tako što češki slikar nekim čudom postaje Ricardov spasitelj jer uviđa da je djetetu pala vrućica i najavljuje ozdravljenje. Zbog toga ga u obitelji doživljavaju kao sveca. Francesco Milans objašnjava mu važnost da Ricardo preživi: „Ova smeđa zemlja, što je vidite svuda okolo, to smo mi. Dali smo ime zemlji i ime obitelji. Zato je potrebno da nijedno od njih ne nestane." ${ }^{23} \mathrm{U}$ taj čas svi su uprli poglede prema Ricardovoj sobi pa čak i „žene, koje su se udale u obitelj, ali su također nosile polovicu odgovornosti za njezino održanje". ${ }^{24} \mathrm{Naš} \mathrm{je} \mathrm{pripovjedač} \mathrm{ovim} \mathrm{tre-}$ nutkom toliko ganut da zaključuje: „Nikad prije nisam jasnije osjetio mističnu moć spoja krvi sa zemljom i obitelji s domom kao u tih nekoliko časova." ${ }^{25}$

\section{4. Zazor od ženâ}

Iako se obezvrjeđujuće opaske o ženama mogu smatrati općim mjestom patrijarhata, u ovom se romanu mizoginija razvija paralelno s fascinacijom muškarcima i fatalnom muškom ljepotom, što nadilazi uobičajene svjetonazorske ograde patrijarhata. U Roušarovu životu i srcu nema mjesta za žene.

Već na početku putovanja koje se čini putom spoznaje, javlja se još jedan motiv - bijeg od žene - roussillonske udovice Marie-Thérese na čijem je vinogradarskom imanju češki slikar radio kao najamni radnik, sve dok mu nije diskretnim promjenama izgleda dala naslutiti naklonost. Ona se, naime, počela šminkati „umjetnim crvenilom” za obraze i nositi grudnjak, što je Roušara sablaznilo, pa je on, čim je zapazio da su njezine grudi „nekad bujno raspuštene po grudniku, sada stegnute i sapete, vještačkim načinom svedene natrag na djevojački oblik”, gotovo izbezumljen odlučio „udaljiti se od horizontalnog poimanja njenog života, kao i jasnih planova koje je imala sa mnom, točnije - koje je imala sa sobom". ${ }^{26}$ Zaziranje, strah i nelagoda prema ženskoj seksualnosti ide ukorak $s$ adorativnim odnosom prema muškoj tjelesnoj ljepoti, koja je uvijek indikator „muških” kvaliteta - ponosa, junaštva, viteštva, častohleplja. U romanu se tako izgrađuje vrijednosni sustav koji odgovara jednoj posve „muškoj kulturi”, koja je postavljena nasuprot „ženskoj kulturi", nagonskoj, koristoljubivoj, i po svemu inferiornoj.

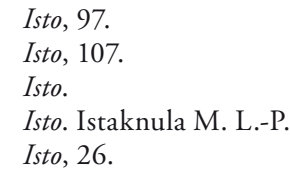


Prema ženama Roušar ipak nije ravnodušan, on ih doživljava isključivo kao vrlo neugodnu smetnju. Kada jednom prigodom nakon besciljne šetnje Barcelonom svraća u neku kavanu u kojoj je „prevladavala kastiljština a katalonski se čuo manje”, ${ }^{27}$ obzirom na njegovo dotadašnje vrednovanje kastiljskog (to je „đavolji jezik”), ne očekujemo da će o atmosferi i gostima biti lijepih riječi. No, i ovdje on prvenstveno suprotstavlja muškarce i žene, a tjelesni opis žena ističe njihovu gotovo zazornu karikaturalnost:

Većina je muškaraca nosila uniforme, jedan dio časničke uniforme na ramenima. Bili su to mladi, vitki ljudi. Mnogo divnih glava s visokim čelom i valovitom kosom. Djevojke su se dobrim dijelom osakatile time što su kosu obojadisale zlatno, što nikako nije odgovaralo južnjačkom licu onako kako ga je zamislila priroda. Njihove su crne oči bile širom rastvorene i još podcrtane crnilom, usne gusto naličene, nokti crveni, kao što to rade žene nekih plemena zapadne Afrike. U tjelesnoj ljepoti bile su ispod razine svojih partnera. Muškarci su bili ljupkiji. ${ }^{28}$

Konačno, kada Roušaru njegov novostečeni prijatelj Ramon Torres, objašnjava motive koje su naveli Carmen da se izloži opasnosti i pomogne u bombardiranju ranjenom Roušaru, dok je on sâm pobjegao izvan grada, on uspoređuje „kršćanske zasade i djela žena” po njihovu „egoizmu i spremnosti na žrtvu”, koje kad se dobro promiješaju daju „žensku dušu”. Analizu završava tvrdnjom da „žene ne spadaju u 'pojedince', kako to zovu učenjaci. Žene su žene”. ${ }^{29}$ Uvrijeđena Carmen tada optužuje Ramona za kukavičluk (ona nije "pojedinac” pa se smije bojati, ali "caballero, čovjek stvaralac” ne bi smio osjećati strah), a Miroslav Roušar joj odrješito i strogo kaže da nema pravo jer "najjači i najsmioniji muškarac može biti otjeran nečim, čemu se ne može oduprijeti". ${ }^{30}$ Ta nevjerojatno neugodna međurodna solidarnost kroz bratimljenje u strahu, kao i nadmeni cinizam, kojim se opravdava kukavičluk muškarca, a ženu optužuje za egoizam i kad čini djela iz milosrđa, ove retke stavlja u sam vrh mizoginijske književnosti, posve na tragu zaključaka Heinricha Institorisa i Jacoba Sprengera da je žena inferiorna muškarcu jer je načinjena od savinutog rebra, pa je zbog tog nedostatka ona jednostavno „nesavršena životinja, uvijek prijetvorna”. ${ }^{31}$ Tako „nesavršena životinja”, koja se još od Aristotela smatra nedovršenim bićem ili nepotpunim muškarcem, nije bezopasna kako bismo očekivali, pa je u patrijarhalnim društvima treba stalno nadzirati. U Nemečekovu se romanu utvrđuje, i to u Ramonovoj posve ozbiljno shvaćenoj analizi predratnog španjolskog društva, da je glavna pogreška, mrlja i nedostatak toga društva upravo - španjolska žena!

(...) španjolska žena, u mladosti obično tjelesno vrlo lijepa, koja je morala biti povučena i nije sudjelovala u španjolskom životu jer ga nije razumjela i nije je zanimao. Istina, u pravilu je rodila mnogo lijepe djece, ali ako nije imala nijedno, ipak je na svoju domovinu, na Španiju, gledala kao na lijepi sag, zanimljivo vezivo, zabavan perivoj - a nikad kao na tvrdu i vlažnu zemlju (...) Salon, beskonačni razgovori, beskonačne brbljarije naličenih ljepotica, one bezbožne „tertulias", kazališta, borbe s bikovima, jutarnje svete mise iz običaja, ovdje u Kataloniji i na sjeveru $\mathrm{k}$ svemu tome i kavane, a u Andaluziji karte, balkoni, vrtovi, to je njezin svijet. ${ }^{32}$

Isto, 213.

Isto.

Isto, 221.

Isto, 222.

Heinrich INSTITORIS - Jacob SPRENGER, Malleus Maleficarum, Zagreb 2006.

Isto, 167. 
Budući da predstavlja neku vrstu hibrida Hesiodova truta i isprazne senzualnosti Molly Bloom, ta se španjolska žena brine isključivo za svoj „mali udobni svijet” u kojemu su svilene čarape, francuski parfemi i čokolada jedina motivacija, a sve ostalo joj je, kako to uzastopno ponavlja lijepa Carmen, „kraljevski svejedno”.

Aksiološki sustav romana u cjelini počiva na binarizmu - Katalonija/Kastilja; muškarac/ žena; tradicija/modernost; patrijarhalni poredak/revolucionarne promjene; maskulinizirana/ feminizirana (kultura, društvo); razum/nagoni; čistoća krvi/miješanje i hibridnost. Te opreke dio su nadređenog (mitskog) sustava u kojem traje vječni sukob načela reda i načela kaosa, koje su između ostalog predstavljene i kao sukob religijskog i antireligijskog načela. Konačno, Đavao koji se javlja i u naslovu, očigledno je izabrao stranu u ovom sukobu - taj izbor nije konvencionalan, dakle nije se priklonio ni falangistima ni revolucionarima, ali je izabrao kastiljski jezik kojim govore vojnici koji pale crkve i ubijaju svećenike. Red je na strani patrijarhalne, religiozne, maskulizirane, viteške Katalonije, a kaos je isto što i žensko načelo, revolucionarni nered, hibridna i miješana kultura. Đavao je, dakle, izabrao Kastilju, kaos, revoluciju i ženu, a Bog je na strani muškarca osobito ako je čistokrvni Katalonac, „latinske rase”.

U početku prividno nametnuta opreka pacifizam/militarizam ne pokazuje se značajnom i do kraja romana postaje ispražnjena, neutralizirana osebujnim razumijevanjem koje pripovjedač iskazuje za rat. Naime, jedino se po pitanju opravdanosti revolucije izražava sumnja: „zar se ratovi na koncu ne vode za veći komad kruha? Nakon svake revolucije tog je kruha manje i nije bolje razdijeljen?"33 No, pacifizam s kojim umjetnik kreće na put spoznaje do kraja romana izgubi se; potone u poplavi diskriminatornih tvrdnji o Drugima, pa ne iznenađuje kada se na kraju noćno bombardiranje Barcelone pokušava protumačiti kao sukob „dviju istina”: „Ostalo je jedno i sigurno: nepoznati je čovjek bacao ovdje na nepoznate ljude naglu smrt, a radio je to u ime jedne istine stavljene protiv druge istine." ${ }^{34}$ Ova naizgled bezazlena, pomirljiva teza, ne može nas ostaviti ravnodušnima jer je posve nerazjašnjeno uime koje bi to istine bombarder Luftwafe mogao zasipati bombama Barcelonu. Pacifizam s početka romana postupno se pretvara u razumijevanje rata. Roušar odlazi u Španjolsku da bi shvatio razloge rata - da bi racionalizirao rat, da bi iz blizine analitički pristupio onima koji umiru i onima koji ubijaju, onima koji napadaju i koji se brane - bez potrebe da zauzme stav, jer on je hladni promatrač. Problematično je jedino to što tu svoju hladnu promatračku poziciju naziva viteštvom, a ratni voajerizam uspoređuje s idealizmom plemenitog Don Quijotea. Kada na kraju ustvrdi - „nema naroda bijele rase, koji bi ratne strahote mogao podnositi s takovom postojanošću kao ljudi s Iberskog poluotoka” 35 - on iskazuje divljenje Španjolcima, ali posredno i divljenje ratu u kojemu su imagem o španjolskoj postojanosti može iskazati kao rasna premoć.

Fotezov prijevod ostao je jedini prijevod Němečekova romana, koji ni Francova zabrana nije učinila popularnijim „drugoj strani”, iako bismo možda upravo to očekivali. Franca je Němečekov roman zasigurno naljutio zagovaranjem autonomne Katalonije, ali priklonjenost Kataloniji proistekla iz patrijarhalnih, gotovo feudalnih srednjovjekovnih načela, osnaženih rasističkim diskursom koji njeguje opća mjesta zastupljena i u retorici nacističke Njemačke, nije mogla steći naklonost šire publike.

\footnotetext{
Isto, 48 .

34 Isto, 191.

35 Isto, 224.
} 


\section{Marko Fotez i kazališne metropole ratne Europe ili „pustimo sve na stranu i promatrajmo biele oblačke”}

Za rekonstrukciju „metropolske” kulturne klime ratne Europe, dragocjeni su Fotezovi putopisi i kazališne impresije obavljene u zbirci Theatralie (1944.) - Mnogo teatra u mnogo gradova (1934.), Kroz kazališta Italije (1939.-1940.) i Mozartov tjedan u Beču (1941.).

Osim navedenih tekstova, u jednom od svojih ranijih putopisa Kamenčići putničkog mozaika (1935.), objavljenom u zbirci Mozaik (1944.), Fotez iznosi, za njega vrlo rijetka, zapažanja aktualne političke propagande, u ovom slučaju vezano uz brutalne antisemitske napise salcburškog dnevnika, kako ozbiljne rubrike, tako i humorističkih priloga:

Salzburški dnevnik izašao je danas u posebnom izdanju. Sav je posvećen razpravi, koja se u Magdeburgu vodi protiv nekog Židova, koji je kao upravitelj jedne škole obezčašćivao svoje učenice. Tu su slike raznih židovskih tipova, koji se prepoznaju po „zavinutom nosu” ili po „utisnutim ušima”, pa natpisi mastnim slovima: Cuvajte svoju njemačku krv. Tko poznaje Židova poznaje vraga. Čuvajte svoje žene i kćeri, Židovi su do u dno duše prokleta rasa. Žene i djevojke, Židovi su vaša propast, itd. Na naslovnoj strani humorističkog lista naslikano je u raznim položajima 18 ljudi, a dolje stoji natpis: Ovdje ima 18 Židova. 4 od njih su protestanti, a 5 katolici. Ali svi zajedno su ipak samo prokleti Židovi. Tko pogodi, koji su katolici, koji protestanti, a koji ortodoksni Židovi, dobije nagradu! ${ }^{36}$

Nakon toga, bez ikakva komentara ili stilskog prijelaza, Fotez nastavlja šetnju okolicom Salzburga u podne po vedrom danu, uočava „biele oblačke” oko alpskih vrhunaca, a kada zazvone podnevna zvona on proživljava „najdivniju simfoniju alpskoga svieta” te se „blažen u doživljavanju čiste prirode bacio u zelenu travu, koja je mirisala, pjevala i vrila milijunima svojih divnih života". ${ }^{37}$ I tu je kraj ovog salcburškog ulomka.

Naglom promjenom raspoloženja i atmosfere u ovom kratkom tekstu, na gotovo šokantan način Fotez suprotstavlja dva oprečna narativa - jedan koji pripada glasilu austrijske javnosti, vezan uz grozomorne aktualne progone Židova, govor pun demonske mržnje, is druge strane bezazleni, djetinji ushit ljepotama prirode i „milijunima divnih života”. Teško je zaključiti može li se opaska o "milijunima divnih života” dovesti u vezu s prethodnim pejorativnim napisima o različitim tipovima „prokletih Židova” ili sve jednostavno treba pripisati Fotezovoj mladenačkoj neozbiljnosti, no ova posljednja sintagma djeluje osobito zastrašujuće kada uzmemo u obzir da je tekst objavljen 1944. godine, kada su uistinu „milijuni divnih života" izgubljeni u bjesnilu koje je slijedilo atmosferu salcburškog tjednika. Kontrapunktiranje dijametralno suprotnih emocija, refleksija i atmosfere, postavljanje „teških misli" u savršen krajolik, a da se pritom emotivna i refleksivna prednost daje krajoliku, ima učinak provokacije; no, ni u ovom slučaju ne možemo znati je li to bila Fotezova namjera ili je to samo slučajna posljedica sustezanja od komentara onda kada je čitatelju neophodan i kada ne očekuje ležernost ni površnost.

U zbirci Theatralie zabilježeno se još jedno dragocjeno Fotezovo iskustvo. Godinu dana prije ovog salcburškog odlomka, 1934., Fotez je u Heidelbergu prisustvovao otvaranju

\footnotetext{
Marko FOTEZ, Mozaik. Putopisi, Zagreb 1944., 21.

37 Isto.
} 
Reichsfestspiele, ${ }^{38}$ koje su obilježene predstavom Der Weg ins Reich. Fotez ima tada tek 19 godina, ali atmosferu u Heidelbergu zapaža odmakom zrelog cinika:

Tu su orgije Hitlerovih zastava. Lepršaju Hackenkreuzi po zraku, penju se po balkonima, pletu se po žicama i stupovima, vise po fasadama, skaču po tramvajskim i autobusnim prozorima, plešu po svim izlozima i umorni sjedaju u zapučke kaputa. I sigurno kroz širom otvorene očne rupe zasjednu i u mozgove. ${ }^{39}$

Erica Fichter Lichte predstavu Kurta Heynickea Der Weg ins Reich spominje u kontekstu kazališnog pokreta Thingspiel koji je trajao od 1933. do 1936., a predstavljao je kombinaciju pučkog kazališta, masovnog spektakla i političkog mitinga. Prototip takvog žanra je drama Deutche Passion Richarda Euringera, koja je praizvedbu imala 28. srpnja 1934. u Heidelbergu. Model drame koju je utemeljio Euringer počiva na poetičkim elementima ekspresionističke lirike i drame, korske igre i kršćanske mitologije. Također, to je i ritualno kazalište koje njeguje Frazerov obrazac smrti kao ponovnog rođenja, samo što se u njemačkoj drami uskrsnuće ne odnosi na Boga nego na naciju.

Fotez nam vjerno prenosi „radnju” Heynickeova komada, a određeni su segmenti osobito značajni zbog usporedbe s prethodnim osvrtom na salcburški tjednik. Dakle, na petsto metara viskom amfiteatru najprije se začuju tri topa, pa fanfare, a zatim bubnjevi. Na pozornicu izlazi odred vojnika, pa odred radnika.

Pale se reflektori. Vojnici u pozadinu, radnici napried. Dolazi čovjek u crvenoj košulji i drži programni govor. Izlazi hitlerovac i iznosi program novog poretka, novog života, nove sreće u Hitlerovu carstvu. Pale se i drugi reflektori. Puk je oduševljen. Veličanstven sprechkor od 400 osoba: Sinut će nam novi život. Sasvim iza publike, na najgornjem kraju amfiteatra, iztrči smiešna prilika u sivom polucilinderu, žutom fraku, bielim hlačama i crnim cipelama. Kroz svinuti nos viče: Ohne mich? Smieh, ruganje. Otjeraju ga u pozadinu zajedno $s$ komunistom (...). ${ }^{40}$

Nakon što maleni dječak donosi baklju, „vatru njemačkih djedova”, daje je Hitlerovcu, koji njome pali četiri smolava stupa visoka dvadeset metara. Ono što slijedi sažeta je poetika Thingspiela, ritualno-propagandnog nacističkog igrokaza:

(...) Tu je 12.000 gledalaca i 1.000 glumaca, plamsaju četiri goleme baklje, pucaju topovi, bubnjaju bunjevi, udaraju vojničke cipele, gore žuti, crveni i bieli reflektori, ogromna masa od 13.000 ljudi diže desnicu i zaklinje se „vatri njemačkih djedova” u hitlerovskim rukama, 13.000 grla pjeva „Deutschland, Deutschland über alles...”"11

Međutim, i u ovom tekstu Fotez ponavlja već viđenu narativnu strategiju - opisao je prizor velikog kalibra, snažno, moćno, trudio se rečenicama u kojima ponavlja brojeve (12 000 gledalaca i 1000 glumaca, 13000 ljudi, 13000 grla), zvukove (topovi, bubnjevi, cipele) i svjetla (četiri ogromne baklje, crveni i bijeli reflektori) dočarati masovnost, monu-

38 Prema podacima koje navodi Erica Fichter Lichte, izvedbom komada Der Weg ins Reich predstavljena je 22. lipnja 1935. nova pozornica na otvorenom, odnosno amfiteatar na Heiligenbergu pored Heidelberga, a tom prigodom je izveden spomenuti komad Kurta Heynickea u režiji Lothara Müthela. Erica FICHTER LICHTE, Theatre, Sacrifice, Ritual: Exploring Forms of Political Theatre, New York 2005., 143.

39 Marko FOTEZ, Theatralia. Clanci i putopisi, Zagreb 1944., 173.

40 Isto, 174.

41 Isto. 
mentalnost pozornice pred kojom zasigurno promatrač ne može ostati ravnodušan. Teško je ne zapaziti da preporod nacije nedvosmisleno isključuje Židove, što je eksplicitno rečeno neugodnim prizorom ruganja servilnoj „smiešnoj prilici” svinuta nosa - to je onaj Frazerov ritualni obrazac novog života kojem prethodi uništenje; u ovo slučaju, cijelog naroda. No, nakon svega slijedi isti zaključak u Fotezovu stilu:

Pustimo sve na stranu. To je teatar. Ogledalo života, zabava puka i pouka puku, veličanstveno naprezanje srdca i mozga, nezaboravni efekt fantazirane mase, teatar sugestivan, jak i vječan... ${ }^{42}$

Ovim odlomkom završava osvrt na Heidelberg Thingstätte. Narativna strategija tipa „pustimo sve na stranu” i promatrajmo „biele oblačke” manje je izražena u njegovoj reportaži s Mozartova tjedna u Beču 1941. godine, sa svečanosti povodom 150 godina Mozartove smrti, koja je organizirana „pod pokroviteljstvom dra Josepha Goebbelsa i Državnog vođe Baldura von Schiracha". ${ }^{43}$ Tada je Fotez odmjereniji, a u njegovoj reportaži nema (mladenačke?) ironije. Ne možemo znati je li promjena pristupa rezultat zrelijih godina ili promijenjenih političkih okolnosti u kojima je poželjno pisati pohvalnice kulturnim događajima organiziranim u nacističkim metropolama, no Fotez bilježi „bogati razpored koji donosi krasan izbor iz Mozartovih 626 djela” te napominje kako „sjajno organizirana ova svečanost pokušava demantirati onu staru maksimu, da među oružjem muze šute". ${ }^{44}$ Fotez vjerno prenosi ceremoniju završne svečanosti povodom zatvaranja Mozartova tjedna:

Kroz počasni špalir SS-odreda stupio je pred žaru Državni Vođa Baldur von Schirach. U taj čas razbio je svečanu tišinu glas govornika kroz zvučnik, koji je sugestivnim i sažetim riječima prikazao značenje ovoga časa, koji budi uspomene na isti momenat prije 150 godina, kad je pred tom istom kapelicom iznesen lies s Mozartovim tielom (...) tek nekoliko najvjernijih prijatelja sabralo se oko liesa, a na samo groblje nije ga pratio nitko. A danas se oko te kapelice viju zastave dvadesetak naroda, niz vienaca čeka da bude položen oko žara, a kroz svemirski eter šire se zvukovi genija, kome sada daje počast čitav sviet. Točno u podne položen je, kao prvi, Hitlerov vienac i u taj čas zazvonila su sva zvona u Beču i Salzburgu (...). ${ }^{45}$

Fotezov „čitav sviet” koji se sakupio na obljetnici Mozartove smrti znatno je reduciran. Kulturni događaj kojim je trebalo proslaviti Mozarta pretvorio se tako u smotru predstavnika Sila Osovine i njihovih saveznika:

Predstavnici naroda odaju počast časkom šutnje. Neki mirno stoje odkrivene glave, neki uzdignute ruke, a zastupnici Japana, Mandžukoa i Thailanda ostaju nekoliko časaka u du-

\footnotetext{
Isto, 174 .

43 Sintagma „Državni vođa” koju je upotrijebio Fotez zapravo je prijevod nacističke titule/čina Gauleiter, što je von Schirachova funkcija u Beču te godine, a znači zapravo vođu nacističke partije za područje Beča. Naime, Baldur von Schirach (1907.-1974.) je kao gorljivi fašist i obožavatelj Mein Kampfa (pročitao ga je za jednu noć) najprije imenovan 1933. godine vođom Hitlerove mladeži, a kasnije je kao bečki Gauleiter bio zadužen za deportaciju 65000 Židova iz Beča u Poljsku. U njegovu govoru 15. srpnja 1942. ta se deportacija spominje kao „doprinos europskoj kulturi”. Usp. Robert Solomon WISTRICH, Who's Who in Nazi Germany, New York 2002., 122.

44 Marko FOTEZ, Theatralia, 231.

45 Isto, 244.
} 
bokom poklonu. I predstavnik Hrvatske sudjeluje u svečanosti. Draga trobojnica utkana je živim bojama u sag naroda. ${ }^{46}$

U tom osakaćenom „cielom svietu”, u društvu onih koji pozdravljaju uzdignutom rukom, Fotez zapaža „dragu trobojnicu”, ne bez stanovitog ponosa.

\section{Zaključak: različiti imagemi zajedničkog imaginarija?}

Kulturni imaginarij određen je kao skup slika o Drugom, koji je zajednički određenoj skupini ljudi. Osnovna jedinica imagološke analize je „slika” tj. skup ideja o stranoj zemlji; diskurzivna tvorba koja počiva na određenom sustavu vrijednosti. ${ }^{47}$ Slika Španjolske u Němečekovu romanu dio je kulturnog imaginarija koji je odnjegovan u konzervativnoj, patrijarhalnoj Europi (Saidovu Okcidentu). U tom su imaginariju također izuzetno važne „nacionalne karakterizacije” ili nacionalni imagemi koji su, kako je to pokazao Leersen, svojim učestalim ponavljanjem zadobili prizvuk poznatosti na kojoj počiva njihova daljnja retorička iskoristivost. ${ }^{48}$ Němečekove slike Španjolske i Španjolaca utemeljene su na stereotipu koji barata ponavljanjem pojmova „viteštvo”, „gospodstvo”, „čast”, „uzvišenost”, „snaga" i slično. Slika Španjolaca ne bi bila sporna da pored pozitivnih imagema koji uzdižu „španjolsku čast” i „španjolski ponos”, u Němečekovu romanu nemamo paralelno istaknute obezvrjeđujuće predodžbe Drugih - Roma, Arapa, ženâ, te u skladu s tim, diskriminatorne prosudbe o pitanjima porijekla, superiornosti, čistoće krvi, hibridnosti itd.

U knjizi koju je naslovio poznatim nacističkim sloganom o nužnoj vezi krvi i tla, Ben Kiernan ističe kako je, proučavajući retoričke i šire kulturološke obrasce koji prethode velikim genocidima u prošlom stoljeću, uočio ponavljanje određenih modela. Izdvojio je obilježja koja predstavljaju rana upozorenja da će se dogoditi katastrofa: rasizam i religijske predrasude, teritorijalni ekspanzionizam, kultovi tradicije i agrarni idealizam. Tako primjerice Němečekovo udivljenje snažnom i mističnom vezom krvi i tla u Kataloniji, koje možemo povezati s nacističkom sloganom Blut und Boden, Kiernan nalazi i u retorici koja prethodi genocidu nad Armencima, u Kambodži, u Ruandi i drugdje. ${ }^{49}$ Ulomci iz salcburškog dnevnika koje nam je prenio Fotez jasno su upozorenje pogroma koji će uslijediti, dok diskurs o Drugima u Němečekovu romanu predstavlja tradicijom i čistoćom rase opsjednutu Europu, dislociranu u Kataloniji, koja je u danom povijesnom trenutku žrtva Španjolskog građanskog rata, no kako je uloga žrtve i agresora u povijesti reverzibilna, žrtva i agresor iznenađujuće često njeguju isti diskurs. Otpornost toga diskursa očigledna je zasluga određenih tvrdokornih stereotipova koje je iznjedrila tradicionalna, patrijarhalna Europa i obnavljala pri svakom susretu s Drugima. Eurocentrizam je prilagodljiv svim nacionalnim reprezentacijama jer proizlazi iz definiranje vlastitog identiteta kroz pripadnost narodu koji

6 Isto, 245.

47 Daniel-Henri PAGEAUX, „Od kulturnog imaginarija do imaginarnog”, Kako vidimo strane zemlje. Uvod u imagologiju, (ur. Davor Dukić, Zrinka Blažević, Lahorka Plejić Poje, Ivana Brković), Zagreb 2009., 125.-150. Ovdje 127.

48 Joep LEERSSEN, „Retorika nacionalnog karaktera: programatski pregled”, Kako vidimo strane zemlje. Uvod u imagologiju, (ur. Davor Dukić, Zrinka Blažević, Lahorka Plejić Poje, Ivana Brković), Zagreb 2009., 99.-124. Ovdje 111.

49 Ben KIERNAN, Blood and Soil: A World History of Genocide and Extermination from Sparta to Darfur, Yale 2007., 37. 
je smješten u središtu, a tako sebe vide svi Europljani. Nacistička retorika samo je ekstreman oblik istoga svjetonazora. Bez obzira na to, neugodna je spoznaja da diskurs utemeljen na rasističkom esencijaliziranju i diskriminatornim nacionalnim imagemima, nije bio ekskluzivno pravo fašizma čak ni u vrijeme fašizma, da je i tada postojao mimo njega, te se nažalost održao i nakon sloma Trećeg Reicha. Na mračne stranputice te retorike i svjetonazora nisu bili imuni čak ni osvjedočeni borci protiv fašizma, poput Němečeka. Kada danas određenu retoriku prepoznajemo kao „fašističku”, dajući time povijesnu dimenziju fenomenu koji nema vremenske granice, i sami upadamo u zamku stereotipa. Njeno je porijeklo već u naizgled bezazlenoj Němečekovoj autorefleksiji o njegovu životu kao običnom životu čovjeka rođenog u srcu Europe - nažalost, to je uobičajena retorika čovjeka koji vidi sebe u središtu Europe, dakle, in medio orbe terrarum.

\section{$\cos$}

\section{Fotez's translation of NĚmeček's novel THE DEVIL SPEAKS SPANISH (I940) IN CONTRAST WiTH HiS OWN TRAVEL JOURNALS FROM THEATRALIA (I944)}

The translation of Němeček's novel The Devil Speaks Spanish, which had been banned through Franco's personal intervention upon its publication in Prague in 1939, was published in pre-war Zagreb in 1940 and, to this day, remains the only translation of the book. The reasons behind Fortez's decision to translate the novel and Franco's decision to ban it can both be traced to the crucial, controversial places of Nemeček's novel, particularly in the way the Spanish civil war is depicted. The novel is structured as a fictional diary and a travel journal/war story written by a Czech painter by the name of Miroslav Roušar. In the conventional manner of a found manuscript, the diary ends up in the hands of the Czech ambassador in Barcelona. The ambassador then becomes the fictional intermediary between the reader and the narrator, who undertakes a journey in search for the causes of the ongoing tragic events of the civil war in Spain. In the interviews which the narrator conducts with other characters (who function as representative stereotypes, or rather, exemplary figures from Spanish society) matters concerning local and national history and Spanish art heritage are discussed. In the process, a "cultural catalogue" of sorts is formed, and a preference towards Catalonia, as the centre of resistance to Franco's forces and a patriarchal utopia facing extinction, becomes evident."The devil's language" in the novel's title is an unmistakable reference to Castilian Spanish, while Catalan becomes a metonym of a superior, idealized arcadian culture which is disappearing in a process precipitated by the reduction of Catalonian autonomy. That alone surely was reason enough for Franco's intervention. Yet, in addition to that, the novel builds value system on a discourse of gender and race discrimination, which becomes evident every time the subjects of body, ancestry, social structure and woman's role in society are broached. From juxtaposing Catalonia to the rest of Spain onwards, the novel constructs an axiological system of binary oppositions expressed through the relationship between patriarchy/revolutionary changes, tradition/modernity, ancestral purity/mixing and hybridity. The opposition between pacifism and militarism which is indicated at the beginning transforms into a very particular understanding of war expressed by the narrator who functions as a neutral spectator while admiring the imagem of the Spaniards' racial superiority demonstrated in the war. 
At the time when the novel was published, Marko Fotez was travelling around Europe, visiting theatres and writing down his impressions about the plays he had seen. By juxtaposing the two travel journals written in "the twilight of Europe" - Nemeček's fictional, banned account of the Spanish civil war and Fotez's real life account of his tour of wartime theatres in Italy and Germany, published in 1944 under the title of Theatralia - the paper analyzes the imagological discourse of a Czech writer and a Croatian translator in relation to the representation of wartime Europe.

Keywords: Zdenek Němeček, Marko Fotez, the Spanish civil war, cultural imaginary, racist discourse

\section{$\cos$}

\section{Literatura}

Snježana BANOVIĆ, Država i njezino kazalište. Hrvatsko državno kazalište u Zagrebu 1941. 1945., Zagreb 2012.

Antonija BOGNER-ŠABAN, Marko Fotez - život i djelo, Čakovec 1989.

Marija CRNOBORI, Životić. Eseji, kazališni i ini, Pula 2011.

Dean DUDA, Priča i putovanje. Hrvatski romantičarski putopis kao pripovjedni žanr, Zagreb 1998.

Erica FICHER LICHTE, Theatre, Sacrifice, Ritual: Exploring Forms of Political Theatre, New York 2005.

Marko FOTEZ, Mozaik. Putopisi, Zagreb 1944.

Marko FOTEZ, Theatralia. Članci i putopisi, Zagreb 1944.

Heinrich INSTITORIS - Jacob SPRENGER, Malleus Maleficarum, Zagreb 2006.

Ben KIERNAN, Blood and Soil: A World History of Genocide and Extermination from Sparta to Darfur, Yale 2007.

Joep LEERSSEN, „Retorika nacionalnog karaktera: programatski pregled”, Kako vidimo strane zemlje. Uvod u imagologiju, (ur. Davor Dukić, Zrinka Blažević, Lahorka Plejić Poje, Ivana Brković), Zagreb 2009., 99.-124.

Zdeněk NĚMEČEK, Đavo govori španjolski, (preveo Marko Fotez), Zagreb 1940.

„Zdeněk Němeček”, Slovnik české literatury po roce 1945.

(http://www.slovnikceskeliteratury.cz/showContent.jsp?docId=426). (11. 3. 2011.)

Zdenek Nemecek Papers. Yale University Library. Beinecke Rare Book and Manuscript Library. (http://drs.library.yale.edu:8083/HLTransformer/HLTransServlet?stylename=yul.ead2002.xhtml.xsl\&pid=beinecke:nemecek\&query=\&clear-stylesheet-cache=yes\&hlon=yes\&big=\&adv= \&filter=\&hitPageStart=\&sortFields=\&view=tp\#titlepage).

Daniel-Henri PAGEAUX, „Od kulturnog imaginarija do imaginarnog”, Kako vidimo strane zemlje. Uvod u imagologiju, (ur. Davor Dukić, Zrinka Blažević, Lahorka Plejić Poje, Ivana Brković), Zagreb 2009., 125.-150.

Robert Solomon WISTRICH, Who's Who in Nazi Germany, New York 2002. 